\title{
Towards a good surface water state in the Flemish Region of Belgium with the Environmental Costing Model
}

\author{
S. Broekx ${ }^{1}$, E. Meynaerts ${ }^{1}$, P. Vercaemst ${ }^{1}$, S. Ochelen ${ }^{2}$ \\ \& A. Beckers ${ }^{3}$ \\ ${ }^{1}$ Flemish Institute for Technological Research (VITO), Belgium \\ ${ }^{2}$ Flemish Environment Administration (AMINAL), Belgium \\ ${ }^{3}$ Flemish Environment Agency (VMM), Belgium
}

\begin{abstract}
The European Water Framework Directive sets ambitious objectives to ensure that all waters meet the requirement of 'good state' by 2015. To achieve this state all EU member states have to develop a river basin management plan including a programme of measures. The Environmental Costing Model for Flanders (Milieukosten Model or MKM in Dutch) provides useful economic insights to assist policy-makers in designing this programme of measures. The Water module of the MKM is a tool to select the most cost-efficient emission reduction measures to obtain a given surface water quality. The optimization model determines by means of standard linear programming techniques the leastcost combination of abatement measures to satisfy multi-pollutant emission reduction targets. The basic model input is an extensive database of (point and diffuse) emission sources and potential emission reduction measures for several sectors including industry, households and agriculture.

Keywords: Water Framework Directive, cost effectiveness analysis, linear programming, water quality.
\end{abstract}

\section{Introduction}

The European Waterframework Directive (WFD) which was adopted in 2000 sets ambitious objectives to ensure that all waters meet good status by 2015 . To ensure this good status will be reached, member states are obliged to publish 
river basin management plans by 2009. Article 9 explicitly mentions the use of economic analysis to ensure an adequate contribution of the different water uses to the recovery of the costs of water services. This economic analysis should make judgments about the most cost-effective combination of measures.

Several initiatives have been or are currently being undertaken to determine this cost-effective combination. Interwies et al. [2] developed a multi-step evaluation process for Germany. This evaluation takes into consideration the ecological effectiveness, the probability of reaching the WFD-objectives until 2015 , the time frame necessary for their implementation and a prioritization with respect to the direct and indirect costs involved. In the Netherlands van der Veeren [3] developed a decision analytic tool that can be used to identify the trade-offs in nutrient management in the Rhine basin between costs and the economic and environmental consequences of nutrient abatement policies in their spatial setting. Further work on modeling the relationship between water and economics in the Netherlands is currently being executed by Brouwer and van den Bergh [1].

In Flanders the BAT-Centre of the Flemish Institute for Technological Research (VITO) started in June 2001, under the authority of AMINAL, with the development of an Environmental Cost Model. The Flemish Government aspires with this project the development of a tool to (i) determine the costs of environmental policy and (ii) contribute to more efficient environmental policy by indicating how environmental targets can be realised in a cost effective way. Initially, the model is developed for the most important industrial air pollution sources in Flanders. By analogy with the test case for 'atmospheric pollution', the BAT-Centre started with a test case for 'pollution of surface water' which focuses on the pollutants $\mathrm{P}, \mathrm{N}, \mathrm{COD}$, the basin of the Nete and multiple emission sources (industry, households, agriculture).

\section{Methodology}

\subsection{Scale to apply cost effectiveness analysis}

The maximum level of detail which can be achieved is determined by data availability. Water quality and quantity data are available for the study area on the level of a VHA zone. These zones are determined in the Flemish Hydrographic Atlas (VHA) and are based on merging points and river characteristics. They are comparable with water bodies as defined in the WFD.

Emission data are available on a more detailed level, depending on the sector. For larger industrial emission sources and waste water treatment plants (WWTP's) individual data are available. For smaller industrial sources which are not monitored into detail and diffuse sources such as population not connected to sewage systems and agriculture data are available on a more aggregated level.

Limiting factor therefore remains quality and quantity data. Quality targets have to be reached at the end of each VHA-zone and emission data are linked to these end points. 


\subsection{Translating quality standards into daily reduction targets}

Common practice for evaluating water quality is comparing actual concentrations with concentration objectives. As concentration objectives are not explicitly determined in the WFD, current quality-standards are used. These standards stipulate a maximum concentration which cannot be exceeded in $90 \%$ of the measurements.

Differences between actual measurements and standards are translated into daily reduction targets to determine the optimal abatement strategy. To do so observed differences are multiplied by daily flow rates. Hence total daily emissions exceeding the target are determined. When concentration targets are already reached in the reference situation, the excess value becomes negative. A reduction of daily emissions by the $90 \%$ largest daily excess value ensures concentration targets are reached.

This methodology enables to optimize irrespective of flow rates. It is comparable with the development of yearly emission ceilings for air pollution and simplifies the Cost Effectiveness Analysis. To be sure that quality standards are reached, simulation of the optimal measurement package with a water quality model is foreseen.

\subsection{Emission sources}

As objectives are specified as daily emission reduction targets, source emission data are quantified as average daily emissions. How these emissions are estimated depends on the type of emission source.

\section{Industry}

Largest polluters are individually monitored. Based on these measurements average daily emissions are estimated. The vast majority of enterprises which contribute less to emissions are not monitored. Though quality data are not available, water use of these enterprises is known. Average daily emissions per sector per municipality are estimated by grouping enterprises on a sector level and municipality level and calculating average emission concentrations of monitored enterprises of the same sector,

\section{Households}

The number of inhabitants per municipality and the percentage of this number connected to sewage systems are known. Average emissions per inhabitant are based on figures used by the Flemish Environment Agency (VMM).

\section{Agriculture}

Emission sources are mainly diffuse. Emissions are complicated to estimate. Results of the water quality model SENTWA, which is specifically used by the Flemish Environment Agency to estimate pollution by agriculture, are used. Average daily emissions are calculated per VHA zone. 


\subsection{Designing measures and estimating their effectiveness and costs}

Emission reduction measures are specified on an individual or more aggregated level depending on the level of detail of the source to which it can be applied. Some of the measures considered in the MKM are stated in table 1. For all potential measures effectiveness and costs are estimated. Costs contain both investment costs and operational costs.

Table 1: $\quad$ Measures considered with the Environmental Costing Model.

\begin{tabular}{|l|c|}
\hline Measure & Source influenced \\
\hline Connection to sewerage and WWTP* & Households \\
\hline $\begin{array}{l}\text { Separated collection of waste water and } \\
\text { rainwater }\end{array}$ & Households \\
\hline Building SWTP* for remote houses & Industry \\
\hline Individual treatment of industrial enterprises & Households/Industry \\
\hline Increasing capacity of WWTP & Agriculture \\
\hline Reduction of livestock & Agriculture \\
\hline Manure treatment & Installation of buffer strips along watercourses \\
\hline
\end{tabular}

*WWTP: waste water treatment plant, SWTP: small scale waste water treatment plant.

\subsection{Evaluating cost effectiveness}

The optimization model determines by means of standard linear programming techniques the least-cost combination of abatement measures to satisfy multipollutant emission reduction targets. The formulation of the linear programming equations is based on van der Veeren [3]. The objective function in van der Veeren minimizes costs of abatement measures:

$$
\operatorname{Min} \sum_{i} c_{i} x_{i}
$$

subject to the following constraints:

$$
\begin{aligned}
& \sum_{i, r} T_{N i, r} N_{i} x_{i} \geq R_{N r} N_{0} \\
& \sum_{i, r} T_{P i, r} P_{i} x_{i} \geq R_{P r} P_{0} \\
& 0 \leq x_{i} \leq 1
\end{aligned}
$$

with $\mathrm{x}_{\mathrm{i}}$ the extent to which measure $\mathrm{i}$ is implemented (represented as a fraction), $\mathrm{c}_{\mathrm{i}}$ the total annual costs related to the implementation of $\mathrm{i}, \mathrm{N}_{\mathrm{i}}$ and $\mathrm{P}_{\mathrm{i}}$ the nitrogen and phosphorous abatement due to the implementation of nutrient abatement activity $\mathrm{x}_{\mathrm{i}}$ and $\mathrm{T}_{\mathrm{Ni}}$ and $\mathrm{T}_{\mathrm{Pi}}$ the transport coefficients. These coefficients describe the fraction of nutrient emitted by a certain source which reaches the region $r$ where fractions $\mathrm{R}_{\mathrm{Nr}}$ and $\mathrm{R}_{\mathrm{Pr}}$ of the initial emissions $\mathrm{N}_{0}$ and $\mathrm{P}_{0}$ have to be reduced. 
Transport coefficients can vary between 0 when the discharge point is situated in another tributary or in a region downstream, and 1 when the discharge point is situated in region $\mathrm{r}$.

The former algorithm is elaborated further to incorporate all emission sources and abatement measures described above. Additions were needed to incorporate both fixed investment and variable operational costs and to incorporate abatement measures applied to different kinds of sources at once.

\section{Case study: the Nete river basin}

\subsection{Study area}

The Nete is a tributary of the Scheldt River. The basin is part of the Flanders Region in Belgium. It has a surface of $1673 \mathrm{~km}^{2}$ and a total length of watercourses of $2224 \mathrm{~km}$. Approximately 600.000 inhabitants live in the basin and 4.121 companies are situated inside the region.

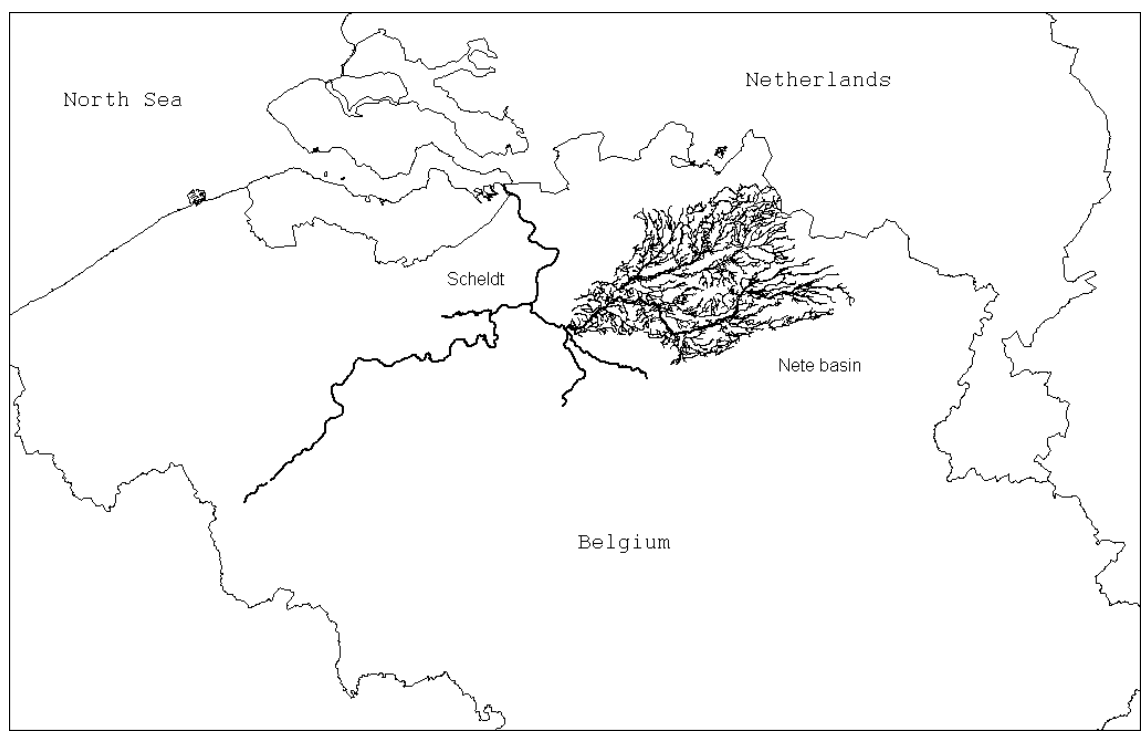

Figure 1: Nete river basin.

\subsection{Water quality}

The physico-chemical water quality of the basin is fairly good. In comparison with the average in the Flemish Region, virtually all physical-chemical parameters measured score better in the Nete basin. However, when comparing measurements with the current water quality standards, it is clear that in a lot of VHA zones standards are not reached. Nevertheless, differences are great between pollutants. The target for Nitrogen is reached in almost all zones, where the target for COD is almost never reached. 
Table 2: $\quad$ Water quality in VHA zones of Nete basin.

\begin{tabular}{|l|c|c|c|}
\hline Water quality & P & COD & N \\
\hline No of VHA zones reaching standard* & 10 & 1 & 19 \\
\hline No of VHA zones not reaching standard* & 10 & 19 & 1 \\
\hline
\end{tabular}

* Vlarem standards P $1 \mathrm{mg} / \mathrm{l}, \mathrm{N} 16 \mathrm{mg} / \mathrm{l}$, COD $30 \mathrm{mg} / \mathrm{l}$ to be reached in $90 \%$ of measurements.

\subsection{Emission sources}

Table 3 gives an indication on the importance of different kinds of emission sources on surface water quality. These percentages are immision rates which means waste water treatment in the reference situation is already taken into account. Households have the largest contribution of all sectors and for all pollutants. Especially their contribution to COD emissions, which are most problematic, is large. The majority of the abatement measures are expected to be taken in this sector.

For a very large amount of total immisions sources are not known. The reasons for this are threefold: the absence as yet of a diffuse pollution inventory, the unknown impact of erosion on water quality and measuring errors. Very little is also known about the influence of agriculture on COD. This means that measures will probably have a larger effect on immisions than is estimated as also the unknown part will reduce. Reduction targets will however only be compared with load reductions on known sources.

Table 3: Contribution of sectors to immisions in Nete basin.

\begin{tabular}{|l|r|r|r|}
\hline Sector & \multicolumn{1}{|c|}{ P } & \multicolumn{1}{|c|}{ COD } & \multicolumn{1}{c|}{ N } \\
\hline Households & $25 \%$ & $35 \%$ & $43 \%$ \\
\hline Industry & $7 \%$ & $16 \%$ & $12 \%$ \\
\hline Agriculture & $9 \%$ & $0 \%$ & $38 \%$ \\
\hline Not known & $58 \%$ & $50 \%$ & $6 \%$ \\
\hline
\end{tabular}

\subsection{Abatement measures}

An inventory of measures on a detailed scale has not yet been constructed. First results will be available at the end of November 2005 .

\section{Conclusions}

The Water Framework Directive explicitly mentions the use of economic analysis to ensure an adequate contribution of the different water uses to the recovery of costs of water services. The Environmental Costing Model has been designed to determine the most cost-effective combination of abatement measures to achieve multiple environmental targets. After first results for atmospheric pollution the model is also being designed for tackling water pollution problems. 
A case study for the Nete river basin, situated in the Flemish region in Belgium, and for the pollutants N, P and COD will be finished in November 2005. First calculations show that a significant amount of measures is needed to achieve current quality standards.

\section{References}

[1] Brouwer R., van den Bergh J., ISES-KIS voorstel: De directe en indirecte waarde van multifunctioneel watergebruik op stroomgebiedniveau, 2005.

[2] Interwies E., Borchardt D., Kraemer A., Kranz N., Görlach B., Richter S., Willecke J., Dworak T., Basic principles for selecting the most costeffective combinations of measures for inclusion in the programme of measures as described in Article 11 of the Water Framework Directive, 2004.

[3] Van der Veeren R.J.H.M., Economic analyses of nutrient abatement policies in the Rhine basin, 2002.

[4] Van Biervliet K., Gielen B., De Sutter R., Le Roy D., Van Tomme I., Leroy I., Van den Broeke G., Pilootstudie Toepassing Milieukostenmodel op het thema oppervlaktewater voor een prioritair bekken: inventarisatie en relaties, 2003.

[5] Paelickx I., Wuyts S., Vannevel R., General Water Quality Plan 2 - Nete, 2001.

[6] Eyckmans E., Meynaerts E., Ochelen S., The Environmental Costing Model: a tool for more efficient environmental policymaking in Flanders, 2004. 